\title{
Classical Form or Modern Scientific Rationalization? Nietzsche on the Drive to Ordered Thought as Apollonian Power and Socratic Pathology
}

\author{
Eli I. Lichtenstein
}

\begin{abstract}
Nietzsche sometimes praises the drive to order-to simplify, organize, and draw clear boundaries - as expressive of a vital "classical" style, or an Apollonian artistic drive to calmly contemplate forms displaying "epic definiteness and clarity." But he also sometimes harshly criticizes order, as in the pathological dialectics or "logical schematism" that he associates paradigmatically with Socrates. I challenge a tradition that interprets Socratism as an especially one-sided expression of, or restricted form of attention to, the Apollonian: they are more radically disparate. Beyond strengthening the case for this basic point, I develop a distinctive account of what, exactly, distinguishes the Apollonian-classical and Socratic forms of order. To this end, I advance interrelated interpretations of Apollonian-classical simplicity and the "cold" calm that it elicits, by contrast to superficially similar Socratic phenomena. This illuminates Nietzsche's broader ambivalence towards science, in part by clarifying the nature and value of an idealized Apollonian science.
\end{abstract}

Keywords: Apollonian and Dionysian; science; will to power; classical; Socrates; idealization

Scientific thought is often viewed as a paradigm of clear, systematic organization-for better or for worse. Like Kant, many people evidently value systematic unity insofar as they take it to distinguish science from any "mere aggregate" of "ordinary cognition." ${ }^{1}$ In this spirit, then, when Carl Hempel or other more recent commentators claim that scientific theories are produced "in an effort to bring order into the diversity of the phenomena we encounter in our experience," they often clearly do so with deeply felt respect for science. ${ }^{2}$ But many other modern critics have been far less impressed by the scientific drive to clear, precise, and systematic thought - in short, by the scientific drive to order. Indeed, many critics find scientific order not just unremarkable, or boring, or limited in scope of valid application, but even deeply pernicious.

Nietzsche is commonly invoked in this context, in the role of a fierce opponent of

$\dagger$ Version of record = Journal of Nietzsche Studies 52.1 (2021): 105-134 [DOI: 10.5325/jnietstud.52.1.0105]

+ University of Michigan, Department of Philosophy; elicht@umich.edu

1 Immanuel Kant, Critique of Pure Reason, trans. and ed. Paul Guyer and Allen W. Wood (Cambridge:

Cambridge University Press, 1998), 691 (A 832/B 860).

2 Carl Hempel, Selected Philosophical Essays, ed. Richard Jeffrey (Cambridge: Cambridge University Press, 2000), 75; compare Hempel's remark elsewhere that "worthwhile" theories provide a "systematically unified account of many different empirical laws" (Carl Hempel, Aspects of Scientific Explanation (New York: Free Press, 1965), 444. Note that even those who stress the "disunity" of science- e.g. see Peter Galison and David J. Stump (eds.), The Disunity of Science: Boundaries, Contexts, and Power (Stanford: Stanford University Press, 1996) - could allow that disjoint patches of scientific inquiry manifest a drive to local order that distinguishes them as truly scientific. 
scientific "rationalism." 3 Thus, the cultural critic Camille Paglia alludes to the popular view that Nietzsche favors irrational "Dionysian" impulses when she claims that "Western science is a product of the Apollonian mind," whose "hope" is "that by naming and classification, by the cold light of intellect, archaic night can be pushed back and defeated" - whereas in fact "[n]ature breaks its own rules whenever it wants," so that "science is always playing catch-up ball." "Paglia in turn associates this "Apollonian"-scientific mind with the idea of a "rational and systematic" cosmos, ${ }^{5}$ and more broadly with "regular, rational mathematical design" 6 or "system and order." In this light, Nietzsche may appear to be essentially an inheritor of the "counterreaction of irrationalism and daemonism which is Romanticism," in opposition to the "Apollonian Enlightenment."

Yet other critics, like Heidegger, have linked pervasive technical order precisely to the triumph of an ethos of Nietzschean will to power. ${ }^{9}$ Leveraging intuitive ties between science and technology, critics of this kind argue that modern science is essentially concerned with controlling things, at least cognitively if not also practically. ${ }^{10}$ Scientific order can thus be viewed as the object of a drive towards calculability and predictability, which Heidegger and others diagnose as a perverse drive to reduce all things to mere "resources" standing by for optimized use ${ }^{11}$ — which they in turn link to a Nietzschean fetishization of power.

Nietzsche's relation to critiques of scientific order may therefore seem schizophrenic. But his actual view is coherent and illuminating, as well as historically influential, even if also widely misunderstood. He takes order, clarity, and simplicity to have a dual meaning and mixed value. On the one hand, they are core features of the kind of "logical schematism" that he associates paradigmatically with Socrates (BT 14) — whose "monstrous lack of any capacity

3 I use "Apollonian" for apollinisch, and I have accordingly adjusted alternative spellings like "Apolline" in quotations from translations or secondary sources, so as to avoid inconsistency.

4 Camille Paglia, Sexual Personae: Art and Decadence from Nefertiti to Emily Dickinson (New York: Vintage, 1991), 5.

5 Paglia, Sexual Personae, 39.

6 Paglia, Sexual Personae, 157.

7 Paglia, Sexual Personae, 25.

8 Paglia, Sexual Personae, 230. Compare Brinton's claim that for Nietzsche "[t]he Dionysian is A Good Thing[...]The Apollonian is A Bad Thing" (Crane Brinton, Nietzsche (Cambridge, MA: Harvard University Press, 1948), 39) (cf. Walter Kaufmann, Nietzsche: Philosopher, Psychologist, Antichrist (Princeton: Princeton University Press, 1974), 128, 168-169). Paglia is likely influenced by Jung's reading of Nietzsche - compare C. G. Jung, "The Apollinian and the Dionysian," in Psychological Types, trans. R. F. C. Hull and H. G. Baynes (London: Routledge, 2017), 125-135.

9 See Micheal E. Zimmerman, Heidegger's Confrontation with Modernity: Technology, Politics, and Art (Bloomington: Indiana University Press, 1990), 34. Compare Ernst Jünger, "Total Mobilization," in The Heidegger Controversy: A Critical Reader, ed. Richard Wolin (Cambridge, MA: MIT Press, 1993), 119-139. See also Iain Thomson, "Technology, Ontotheology, Education," in Heidegger on Technology, ed. Aaron James Wendland, Christopher Merwin, and Christos Hadjioannou (London: Routledge, 2019), 174-193, 179.

10 E.g. see Martin Heidegger, The Question Concerning Technology and Other Essays, trans. William Lovitt (New York: Garland, 1977), 23. On the relation between technological "resource" (Bestand) and scientific "object" (Gegenstand), for Heidegger, see Julian Young, Heidegger's Later Philosophy (Cambridge: Cambridge University Press, 2002), 50-51; Christopher Merwin, Aaron James Wendland, and Christos Hadjioannou, "Introduction: Heidegger's Thinking Through Technology," in Wendland, Merwin, and Hadjioannou, Heidegger on Technology, 1-12, 5-8; Thomson, "Technology," 179-180.

11 See also Thomson, Heidegger's Later Philosophy, chap. 3. 
for mysticism" stemmed from an "over-developed" "logical nature" or "logical drive" (BT 13), and whose naive scientific "optimism" about the power of dialectical method was "as unartistic as it [was] parasitic on life" (BT 24). ${ }^{12}$ But, on the other hand, Nietzsche elsewhere praises drives to simplify, order, and clarify as elements of a vital "classical style," ${ }^{13}$ or as expressions of a basic Apollonian artistic drive to the "calm" contemplation of "images" displaying "epic definiteness and clarity" $(B T 1,5,10,12) \cdot{ }^{14} \mathrm{He}$ contrasts this Apollonian drive with not only a Dionysian artistic drive to intoxication or frenzy (Rausch) in the dissolution of boundaries between clearly individuated forms, but also the distinct, totally unartistic drive of "logical Socratism." 15

These contrasts between Apollonian and classical rather than Socratic kinds of formal clarity have often been mischaracterized, however, and some of their core features have gone unnoted - despite being crucial to understanding Nietzsche's evaluative stance towards modern science. One long-standing interpretive tradition either conflates the Socratic drive with the Apollonian, or else construes Socratism as just an especially intense or one-sided expression of, or restricted form of attention to, the Apollonian. Thus, Walter Kaufmann interprets "the gradual refinement of the Dionysian religion, through Orphism and Pythagoreanism, to Platonism" as "in other words,[...]Apollo's harnessing of Dionysus." 16 Insofar as Nietzsche sees Platonic dialogue as "art becom[ing] overgrown with philosophical thought" under "pressure from the daemonic Socrates" ( $B$ T 14), Kaufmann implies that Socratic culture involves a strong Apollonian drive having "formed" chaotic Dionysian "matter." ${ }^{17}$ In a similar vein, Richard White claims that Nietzsche took "the Apollonian form of Socratic rationalism" to have "triumphed in Greece." 18 So too, Crane Brinton proposes that Nietzsche took Socrates, as "the original rationalist," 19 to reflect a "too-conclusive victory" of

12 I use the following abbreviations: $B T=$ The Birth of Tragedy; $G M=$ On the Genealogy of Morality; $G S=$ The Gay Science; $B G E=$ Beyond Good and Evil; $Z=$ Thus Spoke Zarathustra; $E H=$ Ecce Homo; $T I=$ Twilight of the Idols; $A$ = The Antichrist $W P=$ The Will to Power. I have used the Kaufmann and Hollingdale translations of Nietzsche's works and notes, except where specified otherwise (see n. 3). For the German text of all of Nietzsche's published works and unpublished notes, I have referred to the Digitale Kritische Gesamtausgabe, ed. Paolo D'Iorio, based on the critical text edited by Colli and Montinari (Berlin: de Gruyter, 1967).

13 As Herman Siemens notes, Nietzsche's "overwhelming tendency is to displace the 'classical' age towards[...] the fifth and especially the sixth centuries" ("Nietzsche and the "Classical': Traditional and Innovative Features of Nietzsche's Usage, with Special Reference to Goethe," in Nietzsche and Antiquity: His Reaction and Response to the Classical Tradition, ed. Paul Bishop (Rochester: Camden House, 2004), 391410, 396.

14 While in a narrow terminological sense it is true that "the Apollonian hardly plays a role at all" in Nietzsche's later writings (Max L. Bauemer, "Nietzsche and the Tradition of the Dionysian," in Studies in Nietzsche and the Classical Tradition, ed. James C. O'Flaherty, Timothy F. Sellner, and Robert M. Helm (Chapel Hill: University of North Carolina Press, 1976), 165-189, 165), nevertheless he continues to stress and group many of the features that are captured by his notion of the Apollonian.

15 Compare $B T 13$.

16 Kaufmann, Philosopher, Psychologist, Antichrist, 154.

17 Compare Kaufmann, Philosopher, Psychologist, Antichrist, 238, 281-282.

18 Richard White, “Art and Individual in Nietzsche's Birth of Tragedy," British Journal of Aesthetics 28.1 (1988): 59-67, 65.

19 Brinton, Nietzsche, 87. 
"the Apollonian element" over the Dionysian. ${ }^{20}$ Aaron Ridley associates Socrates with "the hypertrophy of one aspect of the Apollonian." 21 And Julian Young interprets "Socratism" as "Apollonianism transformed from a perspective into a metaphysical dogma": "the view that reality is Apollonian all the way down, so that, in principle, science, together with its offspring, technology, is capable of solving every human problem." 22

This interpretative approach suggests that Nietzsche's essential objection to Socratic dialectic basically concerns its systematic disregard for darker or more pessimistic "Dionysian insights and effects" (BT 8). ${ }^{23}$ But this account is seriously incomplete, at best, if not also deeply misleading or even basically mistaken. Nietzsche does not just criticize Socratism for highlighting only Apollonian phenomena like order, measure, individuality, and "images," at the expense of Dionysian frenzy, dissolution of bounded individuality, or imageless insight. Rather, he also means to be indicating a contrast between two fundamentally distinct kinds of clarity, simplicity, individuality, and so on - in short, between two distinct kinds of order. One of these he values, and associates with Apollo and classicality, as well as with power and vitality. He associates the other with Socratism as a target of his criticism, and with "reason" or "logic" in a pejorative sense. But he also links terms like "logic" directly to "classicality," in a positive sense. ${ }^{24}$ Hence, in short, Nietzsche intends to contrast two fundamentally distinct kinds of order, and by extension two distinct kinds of clearly structured, broadly "scientific" thought -one vital, the other pathological.

My basic aim here includes, but extends beyond, arguing that the Apollonian and Socratic are thus more radically disparate than scholars like Kaufmann and Young suggest. Others have likewise asserted a stronger distinction between the Apollonian and Socratic, although I do offer a more detailed defense of this case than others have, which I take to be valuable in its own right. ${ }^{25}$ However, I also depart further from existing treatments. Namely, I

20 Brinton, Nietzsche, 39. Compare Peter Yates, "Nietzsche, Aristotle, and Propositional Discourse," in Bishop, Nietzsche and Antiquity, 70-78, 77.

21 Viz., "the aspect that gives the world the appearance of being rationally ordered" (Aaron Ridley, Nietzsche on Art (London: Routledge, 2007), 16). (Compare Mulhall's appeal to Socrates's "hyperbolic incarnation of [Apollo's] governing principium individuationis" (Stephen Mulhall, "Orchestral Metaphysics: The Birth of Tragedy between Drama, Opera, and Philosophy," in Nietzsche on Art and Life, ed. Daniel Came (Oxford: Oxford University Press, 2014), 107-126, 120.). Also, see n. 55.) Ridley does allow that Socratic optimism is "neither Dionysian nor (properly) Apollonian" (Nietzsche on Art, 16). But I deny that Socratism truly involves even one rational "aspect" of the Apollonian.

22 JulianYoung, The Philosophy of Tragedy: From Plato to Žižek (Cambridge: Cambridge University Press, 2013), 183. For further details on Young's view and my criticism thereof, see n. 56.

23 And also, in Ridley's case (see n. 21), disregard for non-rational "aspects" of the Apollonian. On Young, relatedly, see n. 56.

24 Cf. O'Flaherty's claim that "the Apollonian mode cannot, by definition, be knowledge" (James C. O'Flaherty, "Socrates in Hamann's Socratic Memorabilia and Nietzsche's Birth of Tragedy," in O'Flaherty, Sellner, and Helm, Nietzsche and the Classical Tradition, 134-143, 136).

25 For other accounts of an Apollonian-Socratic distinction more robust than those posited by Kaufmann, Young, or Ridley, see e.g. O'Flaherty, "Socrates," 137 n. 5; Maudemarie Clark, "Deconstructing The Birth of Tragedy," International Studies in Philosophy 19.2 (1987): 67-75; Douglas Burnham, "Apollo and the Problem of the Unity of Culture in the Early Nietzsche," in Nietzsche as a Scholar of Antiquity, ed. Anthony K. Jensen and Helmut Heit (London: Bloomsbury, 2014), 75-95, 77; Douglas Burnham and Martin Jesinghausen, Nietzsche's "The Birth of Tragedy": A Reader's Guide (London: Continuum, 2010), 92-93; 
develop a distinctive account of what, precisely, distinguishes the Apollonian or classical form of order from the Socratic one, with attention to how this bears on Nietzsche's broader ambivalence towards science. ${ }^{26}$

To focus my discussion, I concentrate on two specific features of Apollonian-classical order: simplicity and the "coldly" calm affect that it elicits - each by contrast to a superficially similar Socratic phenomenon. ${ }^{27}$ I argue, first, that Nietzsche takes Apollonian or classical simplification to involve distilling things down to "tonic" or strength-enhancing features. I then suggest that Apollonian-classical simplicity is helpfully contrasted against two Socratic forms of simplicity, which involve acts of selective focus that fail to artistically "bring out the main features" (TI "Skirmishes" 8) while "exclud[ing]" the "ugly" (KSA 13:14[119]). ${ }^{28}$ What is excluded from Socratic phenomena is not the Dionysian, but power or vitality more generally. Finally, I argue that Apollonian calm is the cold but joyful calm of powerful focus or concentration, reflecting both the ease with which great strength or will to power overcomes resistance, in the focusing subject, and the focused clarity of the idealized forms that she distills and enjoys as pure artistic "semblance." I conclude with brief comments on the nature and value of a hypothetical Apollonian science.

Two methodological notes are in order. First, I will treat "Apollonian" and "classical" order as largely synonymous - albeit with the caveat that Nietzsche sometimes uses "classical" in a more expansive sense, e.g. to refer to "healthy" as opposed to "sickly" or "Romantic" culture, in a way that encompasses both Dionysian and Apollonian drives. ${ }^{29}$ Nevertheless, he also sometimes uses "classical" in a narrower sense that closely conforms to the "Apollonian." 30 Second, when I relate Apollonian order to the will to power, I do not mean to suggest that Nietzsche had conceived of the will to power when he wrote $B T$. Rather, his later works and notes illuminate contrasts that he first draws only more intuitively or inchoately, like that between Apollonian and Socratic culture. The greatest philosophical and historical interest lies in examining evolving Nietzschean categories in their most sophisticated and explanatorily powerful forms.

Andrew Huddleston, Nietzsche on the Decadence and Flourishing of Culture (Oxford: Oxford University Press, 2019), chap. 1. Cf. Porter's claim that “'Dionysus,' 'Apollo,' and 'Socrates' are differences of reading only, slight accentuations and distortions of one another," such that when Socrates appears (in BT), "all the figures of [Nietzsche's] discourse begin to totter[...]over the abyss of a contradictory unity" (David I. Porter, The Invention of Dionysus: An Essay on "The Birth of Tragedy" (Stanford University Press, 2000), 120).

26 E.g. Burnham argues that "the most important difference" between the Apollonian and Socratic is that the former "realizes the illusory character of its beliefs and its productions, but nevertheless ascribes them the highest value," whereas the Socratic "identifies illusion with the absence of value" and "finds morally absurd the assigning of value to that which is" ("Apollo," 77). Burnham and I both stress artistic 'illusion'. But Burnham nowhere mentions order, simplicity, concentration, or focus ("Apollo," 75-95); he mentions intoxication (Rausch) just once, linked to the Dionysian and not the Apollonian (72); and he discusses idealization only in passing (92). More broadly, I take my emphasis on focus or concentration and account of simplification to be especially distinctive.

27 Further aspects of Apollonian-classical order (e.g. stability or individuation) merit examination in further studies.

$28 W P \S 809$.

29 For Nietzschean uses of "classical" in this vein, se Siemens, "Nietzsche and the "Classical," "401-2.

30 E.g. see Siemens, "Nietzsche and the "Classical," 401. 


\section{Apollonian-Classical Simplification as Idealizing Focus}

We may begin to examine Nietzsche's view of simplicity by considering an 1888 note in which he links "[1] ogical and geometrical simplification" directly to "enhancement of strength":

Becoming more beautiful as the expression of a victorious will, of increased coordination, of a harmonizing of all the strong desires[...]Logical and geometrical simplification is a consequence of enhancement of strength: conversely the apprehension of such a simplification again enhances the feeling of strength-High point of the development: the grand style. (KSA $13: 14[117])^{31}$

The same "grand style" that Nietzsche here calls the "high point" of self-reinforcing "simplification," he elsewhere describes as expressive of "[ $\mathrm{t}]$ he highest feeling of power and sureness" (TI "Skirmishes" 11). Similarly, the grand style is "[e]xpression of the "will to power' itself," and is linked to "the classical ideal" as well as to the "highest type" in a "pagan ideal" of "self-affirmation" or "bestow[ing]" $(K S A 13: 11[138]){ }^{32}$ This style's "grand ambition" is "to compel one's chaos to become form: to become logical, simple, unambiguous, mathematics, law" (KSA 13:14[61]). ${ }^{33}$ More concretely, it is exemplified in the Roman Empire: "[t]he imperium Romanum[...], this most admirable work of art in the grand style," with construction "designed to prove itself through thousands of years" ( $A$ 58). In turn, the "Roman style," or "aere perennius ['more enduring than bronze'] in style," is "[c]ompact" and "severe," with "a cold sarcasm" and "as much substance as possible" (TI "Ancients" 10). Finally, this "cold" Roman severity evokes Nietzsche's broader claim that a "species comes to be, a type becomes fixed and strong," only "by virtue of its very hardness, uniformity, and simplicity of form" - the kind of simplicity that is realized in "a type with few but very strong traits, a species of severe, warlike, prudently taciturn men" (BGE 262). ${ }^{34}$

Nietzsche's appeal to a classical ideal involving simplicity and strength is consistent with certain other of his uses of the term "classical," sometimes directly in connection with the Apollonian. ${ }^{35}$ For instance, he takes "Classical taste" to "mean[] will to simplificess" (KSA 13:11[31]). ${ }^{36}$ Here classicality is arguably broader than the Apollonian-foration, strengthening, to visible happiness, to the terrible, the courage of psychological nakedn

$31 W P \S 800$.

$32 W P \S 341$.

$33 W P \S 842$.

34 Likewise, "a quantum of coldness, lucidity, hardness is part of all 'classical' taste: logic above all, [...]concentration, hatred for feeling, heart, esprit, hatred for the manifold, uncertain rambling, for intimations" (KSA 13:11[312]). Compare the characterization of "simplicity of style" and its relation to "strength" in $G S 226$.

35 For a broader overview of Nietzsche's different uses of "classical," in particular vis-à-vis Goethe, see Siemens, "Nietzsche and the "Classical."”

$36 W P \S 868$. 
example, insofar as a will to "the terrible" evokes the Dionysian. But simplification is still evidently a distinctively Apollonian phenomenon, on Nietzsche's view. For instance:

In the Dionysian intoxication [Rausch] there is sexuality and voluptuousness: they are not lacking in the Apollonian. There must also be a difference in tempo in the two conditions - The extreme calm in certain sensations of intoxication (more strictly: the retardation of the feelings of time and space) likes to be reflected in a vision of the calmest gestures and types of soul. The classical style is essentially a representation of this calm, simplification, abbreviation, concentration - the highest feeling of power is concentrated in the classical type. To react slowly; a great consciousness; no feeling of struggle. (KSA $13: 14[46])^{37}$

Here the Apollonian, specifically, is linked to classical "simplification." ${ }^{38}$ Likewise, Nietzsche explains that "'Apollonian' means: the urge to perfect self-sufficiency, to the typical 'individual,' to all that simplifies, distinguishes, makes strong, clear, unambiguous, typical: freedom under the law" (KSA 13:14[14]). ${ }^{39}$ And he suggests that "the Apollonian part of Greek tragedy[] appears simple, transparent, beautiful" (BT 9).

It helps to distinguish several distinct threads within these claims, so as to better grasp their interrelation. First, Nietzsche's appeals to "will to power" and "enhancement of strength" are in keeping with his broader view that life — if not all reality ${ }^{40}$ — is essentially characterized by a drive to "self-overcoming" or the continual expansion of power. ${ }^{41}$ Thus, he claims that the

37 WP $\$ 799$.

38 See also KSA 13:11[294].

$39 W P \S 1050$. See also KSA 13:14[46].

40 E.g. in GM II:12, Nietzsche favorably appeals to the theory of a "power-willing operating in everything that happens." Likewise: "life is merely a special case of the will to power" (KSA 13:14[121]); "Being-we have no idea of it apart from the idea of "living'," for "[h] ow can anything dead 'be'?" (KSA 12:2[172])." Compare BGE 36 (on which see Tsarina Doyle, Nietzsche's Metaphysics of the Will to Power: The Possibility of Value (Cambridge: Cambridge University Press, 2018), 214ff.; cf. Paul S. Loeb, "Will to Power and Panpsychism: A New Exegesis of Beyond Good and Evil 36," in Nietzsche on Mind and Nature, ed. Manuel Dries and P. J. E. Kail (Oxford: Oxford University Press, 2015), 57-88; KSA 12:9[63], 13:14[80, 12:8[1], 12:10[177], 11:38[12]. See also Martin Heidegger, Nietzsche, trans. David Ferrell Krell (San Francisco: Harper Collins, 1991); John Richardson, Nietzsche's System (Oxford: Oxford University Press, 1996), 18 n. 4.

41 While many scholars will resist this strong account of will to power, I take myself to operate within one existing interpretive tradition, including Heideggerand Richardson, which warrants serious consideration alongside others (compare Heidegger, Nietzsche; Richardson, Nietzsche's System). (Richardson aims to "show[] how well[...Nietzsche's] thoughts can be clarified by being organized systematically around [the] partly concealed core" of his theory of will to power (Nietzsche's System, 9). See also Doyle, Nietzsche's Metaphysics of the Will to Power. Cf. Bernd Magnus, "The Use and Abuse of The Will to Power," in Reading Nietzsche, ed. R. Solomon and K. Higgins (Oxford: Oxford University Press, 1988), 218-235; Linda L. Williams, "Will to Power in Nietzsche's Published Works and the Nachlass," Journal of the History of Ideas 57.3 (1996): 447-463; Brian Leiter, Nietzsche on Morality, 2nd ed. (London: Routledge, 2015). By illustrating part of the explanatory power of a "strong" will to power, I hence contribute indirectly to one side of a broader scholarly dialogue about the will to power and the use of Nietzsche's late Nachlass (which I here work to link to published texts) - although my true focus is Apollonian-classical order. I am grateful to an anonymous referee for pressing me to clarify my methodology. 
"really fundamental instinct" of life "aims at the expansion of power," so that "the will to power" is "the will of life" ( $G S 349)$. Likewise, the "will of life" is "bent upon power" (GM II:11), will to power is "the essence of life" (GM II:12), "life itself simply is will to power" ( $B G E$ 259), and life is "the instinct for growth, for durability, for an accumulation of forces, for power" $(A 6) .{ }^{42}$ Nietzsche hence claims either that logical-geometrical simplification is (or can be) an expression of life; or else that it is an expression of will to power-as life is. Although the former option may seem preferable, it is not clearly so. For instance, he describes " [ $[\mathrm{t}]$ hinking" in primitive conditions (pre-organic)" as "the imposition of forms, as in the case of crystal" (KSA 11:41[11]). ${ }^{43}$ So, while "[i]n our thought, the essential feature is fitting new material into old schemas" (KSA 11:41[11]), perhaps Nietzsche means to be subsuming this cognitive activity under a broader category of "making equal what is new" (KSA 11:41[11]) or "imposing form," which encompasses even inorganic phenomena like crystallization. ${ }^{44}$ That is, it is not clear whether he is suggesting that crystallization is like figurative "thinking," or rather that thinking is like cognitive "crystallization." In the latter case, Nietzsche may be entertaining the idea that phenomena like logic and thinking are best understood by analogy to inorganic forms of will to power - that is, by analogy to specifically inorganic expressions of the "power-willing operating in everything that happens" (GM II:12). ${ }^{45}$

Regardless, we should ask: what is simplicity, such that it has anything to do with the "expansion of power"? A first intuitive response is to focus on imposing form: something expands its power by ordering external manifolds in a way that reflects its nature, and which requires overcoming resistance from a field of recalcitrant matter. ${ }^{46}$ Some of Nietzsche's remarks do suggest this view of simplicity. For instance, in seeking to explain why the "fictitious world of subject, substance, "reason', etc." is "needed," he asserts that "there is in us a power to order, simplify, falsify, artificially distinguish," before claiming that " [ $[\mathrm{t}] \mathrm{ruth}$ ' is the will to be master over the multiplicity of sensations:- to classify phenomena into definite categories" (KSA 12:9[89]). ${ }^{47}$ Nietzsche here also associates the imposition of cognitive forms onto "the multiplicity of sensations" with falsification. ${ }^{48}$ Similarly, in $B G E$, he claims that

42 See also $Z$ II: “On Self-Overcoming”; $B G E$ 13; $K S A$ 12:5[71].10.

$43 W P \S 499$.

44 Compare KSA 12:5[14].

45 This point about "crystalline" power is arguably restricted to unpublished notes more so than are the broader claims about will to power reviewed above; see also n. 40, n. 41.

46 "[T] he will to power can manifest itself only against resistances" (KSA 12:9[151]). See also $A$ 2; KSA 13:14[174]; KSA 13:11[75]; GS 56; $B G E$ 260; GM I:10; $E H$ "Wise" 7; $Z$ I: "On War and Warriors."

$47 W P$ §517. Compare Nietzsche's characterization of the beliefs "that there are enduring things; that there are equal things; that there are things, substances, bodies" as "erroneous articles of faith" (GS 110), and his claim that "science at its best seeks most to keep us in this simplified, thoroughly artificial, suitably constructed and suitably falsified world" (BGE 24). See also GS 107, 111, 112; KSA 12:9[144], 11:34[131]; the further passaged cited below in n. 49; and n. 87.

48 For alternative views on the "falsification thesis" that Nietzsche takes all human knowledge to falsify reality, see Maudemarie Clark, Nietzsche on Truth and Philosophy (Cambridge: Cambridge University Press, 1990); Nadeem Hussain, "Reading Nietzsche Through Ernst Mach," in Nietzsche and Science, ed. Gregory Moore and Thomas H. Brobjer (London: Routledge, 2004), 111-129; R. Lanier Anderson, "Nietzsche on Truth, Illusion, and Redemption," European Journal of Philosophy 13.2 (2005): 185-225; Alexander Nehamas, "Nietzsche on Truth and the Value of Falsehood," Journal of Nietzsche Studies 48.3 (2017): 319-346. I take 
within "[g]enuine philosophers" whose " knowing' is creating[...and] will to truth is—will to power" (BGE 211), the drive "to assimilate the new to the old, to simplify the manifold, and to overlook or repulse whatever is totally contradictory" expresses the "spirit's power to appropriate the foreign" by "retouching and falsifying the whole to suit itself" (BGE 230). A drive to simplify and falsify can therefore be a drive to "growth, in a word-or, more precisely, the feeling of growth, the feeling of increased power" (BGE 230). More broadly, Nietzsche takes ordering a manifold to constitute "falsification" insofar as this manifold is a "reality" that resists being artificially organized or formed. ${ }^{49}$

Manifolds resist being formed, on Nietzsche's view, at least partly insofar as they contain "contradictory" elements which a healthy drive to simplify must "overlook or repulse." Here one may helpfully compare his account of "[t]he ugly" as "that which is excluded from art":

All art works tonically, increases strength, inflames desire (i.e., the feeling of strength), excites all the more subtle recollections of intoxication [Rausches][...]

The ugly, i.e., the contradiction to art, that which is excluded from art, its No[...]

The effect of the ugly is depressing: it is the expression of a depression. It takes away strength, it impoverishes, it weighs down[...]A state closely related to the ugly is encountered in logic, too: heaviness, dimness. (KSA $13: 14[119])^{50}$

According to Nietzsche, the "ugly" elements systematically excluded from art are depressive. Similarly, in $T I$, he claims that "everything ugly weakens and saddens man," such that "[h]is feeling of power, his will to power, his courage, his pride - all fall with the ugly and rise with the beautiful" (TI "Skirmishes" 20). In GS, likewise, he claims that "[t] he sight of what is ugly makes one bad and gloomy," and in this light suggests that, in " giv[ing] style' to one's character," "the ugly that could not be removed is concealed," or else "reinterpreted and made sublime" (GS 290). ${ }^{51} \mathrm{He}$ even associates this exclusion of "ugly" elements directly with simplification: "only [artists] have taught us the art of viewing ourselves as heroes-from a distance, and, as it were, simplified and transfigured," which is the "[o]nly" way that we can "deal with some base details in ourselves" (GS 78). In short, then, whereas the ugly takes away strength, art works tonically to increase strength and elicit a feeling of strength. And this is

no stand on this debate here, however. See also n. 87.

49 Compare $B G E$ P; KSA 13:14[79], 12:9[144], 12:9[89], 12:9[97], 12:7[9], 11:26[61], 12:2[142], and 11:36[21] (WP $\S \S 635,521,517,516,510,503,632$, and 655, respectively).

50 WP $\S 809$.

51 "Ugliness" that has been "made sublime" is plausibly related to the "terrible" (not to the "ugly" as that which is excluded from art) and, hence, to the Dionysian as opposed to the Apollonian. Eg. note the association of the "terrible" Dionysian wisdom of Silenus (BT 4; see note 52) with "the ugly and disharmonious" (BT 24). Compare the link of the Dionysian to the "ugly" and "the terrible and questionable" in GS 370. See also KSA $13: 14[14]$. 
plausibly the same feeling of strength that is "enhanced" by "logical and geometrical simplification" (KSA 13:14[117]). Hence, insofar as he takes it to be a healthy form of will to power, Nietzsche evidently takes simplifying a manifold to involve systematically overlooking, repulsing, or excluding elements that are depressive or enervating-including both the ugly in art and the (literal or figurative) ugliness of "heavy" or "dim" modes of logical thought..$^{52}$

In this light, we can see that Apollonian or classical simplification, i.e. the kind of simplification that Nietzsche values, does not ultimately concern the imposition of form. Rather, it is more deeply a matter of systematically excluding depressive or enervating elements from a given "manifold." This artistic exclusion should not be viewed as merely subtractive, however:

If there is to be art, if there is to be any aesthetic doing and seeing, one physiological condition is indispensable: frenzy [Rausch].[...]What is essential in [the frenzy of will] is the feeling of increased strength and fullness. Out of this feeling one lends to things, one forces them to accept from us, one violates them - this process is called idealizing.[...][I]dealizing does not consist, as is commonly held, in subtracting or discounting the petty and inconsequential. What is decisive is rather a tremendous drive to bring out the main features so that the others disappear in the process. (TI "Skirmishes" 8)

Here Nietzsche claims that the artistic "frenzy of will" involves "lending" to things, in the sense of "violating" them or "forcing" them to "accept." This characterization of lending evokes his aforementioned association of "classical" and "pagan" ideals with "bestowing." To lend or bestow, in this sense, is presumably related to the "gift-giving virtue" that Nietzsche's Zarathustra describes as "the highest virtue" and opposes to "degeneration." Gold thus attained "the highest value" because "it is uncommon and useless and gleaming and gentle in its splendor; it always gives itself" ( $Z$ I : "On the Gift-Giving Virtue" 1). But Nietzsche also characterizes this kind of aggressive lending as idealization, and insists that it involves not merely "subtracting or discounting the petty and inconsequential," but also a creative process of "bringing out the main features so that the others disappear in the process." The result is a certain kind of simplicity: an idealized form comprising only "main" features.

Nietzsche thus values simplification construed as artistically "bringing out main features" in things, while systematically excluding the others. Here the excluded "others" are ugly or enervating features. And "main" features are those that work tonically to increase strength and enhance the feeling of strength. This feeling of strength is precisely what Nietzsche means by "frenzy" or "intoxication" (Rausch), in his later works and notes. This marks a departure from his earlier use of the term, in $B T$, where he instead maps the distinction between Apollonian and Dionysian drives onto dreams and intoxication, respectively (BT 1).

52 Compare Nietzsche's description of "the ugliness and noisiness of all direct dialectics" (KSA 13:11[375] / WP §427). 
On his later and more expansive usage, however, "intoxication" or "frenzy" is a generic term for a distinctive state that all art elicits, and which itself gives rise to art. Hence: "the effect of works is to excite the same state that creates art-frenzy [Rausch]" (KSA 13:14[47]); ${ }^{53}$ "Apollonian and Dionysian, both conceived as kinds of frenzy" (TI "Skirmishes" 10). This basic artistic state - this creative "condition of pleasure called frenzy"-is "precisely an exalted feeling of power" (KSA 13:14[117]). ${ }^{54}$ And simplification elicits this artistic feeling of power by means of systematic falsification, on Nietzsche's view. So, the result is an idealized form that one may contemplate as beautiful semblance (Schein). ${ }^{55}$ Apollonian-classical simplification thus yields simplicity in the sense of a state of distilled power or focused strength - as in the "compact" substance of the Roman style.

\section{Socratism as Naive 'Cheerfulness' and Scientistic 'Reasonableness'}

In this light, we may better appreciate the kinds of simplicity that Nietzsche criticizes. When simplification does not involve using "tonic" capacity as a criterion for artistic selection and exaggeration, or using enervating "ugliness" ("dimness," etc.) as a criterion for exclusion, it yields forms of simplicity that Nietzsche does not value. Two such processes are especially salient: first, simplification that systematically excludes the "terrifying" Dionysian "abyss"rather than excluding the enervating or the ugly, in the above sense; and second, simplification that uses "reasonableness" (Vernünftigkeit) as a selection criterion. For ease of reference, we may say that these processes respectively yield naive and scientistic forms of simplicity. Nietzsche's attack on Socratism in $B T$ involves criticizing both of these forms of simplicity.

Naive simplicity arises from systematically excluding the painful and terrifying aspects of reality that Dionysian artistic insight highlights. The result is simple in the sense that childlike states are simple: untroubled or carefree, as in the "Greek cheerfulness" or the "cheerful optimism" of Socratic-theoretical man which Nietzsche harshly criticizes in BT. Here Nietzsche's main objection to the cliché of Greek cheerfulness appears to be that it indicates a basic failure to respect the world's "Dionysian underground" (B T 25). And this in turn encourages an interpretation of Socratism as a one-sided expression of the Apollonian drive, or as a worldview focusing only on (some or all) Apollonian phenomena-e.g. recall Young's account of Socratism as the view that reality is "Apollonian all the way down." ${ }^{56}$ But, in fact,

$53 W P \S 821$ (written in 1888).

54 WP $\S 800$ (1888).

55 Rethy and Stoll also discuss the link between the Apollonian and semblance, but without relating this to idealization, Rausch, simplifying to "tonic" features, focus or concentration, etc.-compare Robert Rethy, "Schein in Nietzsche's Philosophy," in Nietzsche and Modern German Thought, ed. Keith Ansell-Pearson (London: Routledge, 1991), 59-87; Timothy Stoll, "Nietzsche and Schiller on Aesthetic Semblance," The Monist 102.3 (2019): 331-348. On Burnham, relatedly, see n. 26.

56 Young claims that Nietzsche uses "Apollonian" in "two senses" in BT: the first means "the everyday world" of the principium individuationis; the other means "this same world raised to a state of glory in Homeric art" (Julian Young, Nietzsche's Philosophy of Religion (Cambridge: Cambridge University Press, 2006), 17; see also Young, Philosophy of Tragedy, 173). But Nietzsche's early view, in BT, is that one Apollonian drive yields both "everyday" objects and Homeric art: even the everyday world is created by an "amoral artist-god" (BT "Attempt" 5). Everyday objects thus only appear mundane - perhaps especially to "reasonable" Socratics. Compare Rethy's claim that, in $B T$, the "primary aspect" of "the world in its finite, individuated measure" 
naive exclusion of the Dionysian neither stems from the Apollonian drive nor reflects onesided emphasis on only Apollonian aspects of reality.

To see this, it helps first to review some basic historical context for Nietzsche's early criticism of the concept of "Greek cheerfulness" (,griechischer Heiterkeit") —which we may then contrast against his approving description of a kind of serene "cheerfulness" (Heiterkeit) or "calm" (Ruhe) that he explicitly associates with the Apollonian drive. ${ }^{57}$ As he says in the preface to a new 1886 edition of $B T(1872)$, his younger self had been "obsessed" with "the question marks he had placed over the alleged "cheerfulness' of the Greeks" (BT "Attempt" 1). The relevant notion of Greek cheerfulness had become something of a cliché within $18^{\text {th }}$ - and $19^{\text {th }}$-century German Classicism, now perhaps most famously encapsulated in Winckelmann's 1755 dictum that the "most eminent characteristic of the Greek works is a noble simplicity and sedate grandeur in Gesture and Expression." 58 Greek figures thus indicate a "great soul" that "lies sedate beneath the strife of passions," just "as the bottom of the sea lies peaceful beneath a foaming surface." 59 (More broadly, "simplicity and calmness" is "the true sphere of [the soul's] action." ${ }^{\prime 00}$ ) Winckelmann ties this "noble simplicity and sedate grandeur" to an idyllic state of harmonious play, in which the "happy inhabitants" of ancient Greece were "devoted to mirth and pleasure," and the artist "enjoyed nature without a veil." ${ }^{61}$ It is precisely this traditional classicists' image of the happy and innocent Greek, free from all troubling passions and directly connected to nature in childlike simplicity, which Nietzsche rejects as "cheerful," in a pejorative sense. ${ }^{62}$ And he evidently views this sort of mythic "Greek cheerfulness" as similar to the "cheerful optimism of theoretical man" (BT 19) that he identifies in Socratic dialectic, Euripidean tragedy, Platonic dialogue, Aristophanes's New Comedy, and certain aspects of modern scientific thought.

On Nietzsche's view, Apollonian "cheerfulness" differs from naive "Greek cheerfulness" insofar as the former is directly responsive to the "primordial pain" at the world's core:

(which "the plastic artist reproduces in his own imitatio Dei") is Schein: "not a 'mere appearance', but a "beautiful shining"” ("Schein in Nietzsche's Philosophy," 65). Young's first sense of "Apollonian" is too close to the Socratic, and the disunity of his two senses is problematic.

57 I translate Heiterkeit as "cheerfulness" rather than "serenity" throughout, for consistency. To bring out the sense of calm or having "no feeling of struggle" (KSA 13:14[46]), I sometimes use phrases like "serene cheerfulness."

58 Abbé Winckelmann, Reflections on the Painting and the Sculpture of the Greeks, trans. Henry Fuselli (London: A. Millar, 1765), 30.

59 Winckelmann, Reflections, 30.

60 Winckelmann, Reflections, 32.

61 Winckelmann, Reflections, 9. On Nietzsche vis-à-vis Schiller and the "naive," see also Brent Kalar, "The Naive and the Natural: Schiller's Influence on Nietzsche's Early Aesthetics, " History of Philosophy Quarterly 25.4 (2008): 359-377.

62 On Nietzsche's relation to Classicism, see Dirk t. D. Held, "Conflict and Repose: Dialectics of the Greek Ideal in Nietzsche and Winckelmann," in Bishop, Nietzsche and Antiquity, 411-424; Christian J. Emden, "The Invention of Antiquity: Nietzsche on Classicism, Classicality, and the Classical Tradition," in Bishop, Nietzsche and Antiquity, 372-390; Paul Bishop and R. H. Stephenson, Friedrich Nietzsche and Weimar Classicism (Rochester: Camden House, 2005); Thomas H. Brobjer, “Sources of and Influences on Nietzsche's The Birth of Tragedy," Nietzsche Studien 34.1 (2005): 278-299, 281-283. Note Brobjer's claim that Nietzsche seems not to have actually read Winckelmann ("Sources," 283). 
The Greeks knew and felt the terrors and horrors of existence; in order to live at all they had to place in front of these things the resplendent, dream-born figures of the Olympians. That enormous distrust of the Titanic forces of nature, that moira which throned, unpitying, above all knowledge, that vulture of man's great friend, Prometheus, that terrifying lot drawn by the wise Oedipus, that curse upon the family of Atreus which compels Orestes to kill his mother, in short that whole philosophy of the wood-god ${ }^{63}[\ldots]$ - all this was constantly and repeatedly overcome by the Greeks, or at least veiled and withdrawn from view, by means of the artistic middle world of the Olympians. (BT 3)

Nietzsche hence claims that Apollonian culture "must have triumphed over an abysmal and terrifying view of the world and the keenest susceptibility to suffering" ( $B T 3)$. This victory over the "gloomy abyss" ( $B T$ 17) which we intuit in Dionysian art yields true Apollonian cheerfulness or a genuine "Olympian divine order of joy" $(B T 3)$-by contrast to the shallow "cheerfulness of slaves who know no graver responsibility, no higher ambition, nothing in the past or future of higher value than the present" $\left(B T\right.$ 11). ${ }^{64}$

Nevertheless, for several reasons, we should find unsatisfactory an account of Greek cheerfulness as anything like "Apollonian serenity divorced from Dionysian pain and horror." First, Nietzsche clearly distinguishes between different underlying motives or causes for states of dispassionate "calm" or serene "cheerfulness." He approves of some of these grounds for calm (e.g. "gaining victory over suffering"), whereas he criticizes others (e.g. "knowing no graver responsibility, no higher ambition"). Thus, it makes little sense to characterize the slavish Socratic state of "knowing no graver responsibility" as rooted in a "too-conclusive victory" of the Apollonian drive over the Dionysian (contra Brinton), in a view of reality as "Apollonian all the way down" (contra Young), or in the "hypertrophy of one aspect of the Apollonian" (contra Ridley). There is nothing genuinely Apollonian about "knowing no graver responsibility."

Second, there are also plausibly basic qualitative differences between the forms of "cool" serenity or calm that result from Apollonian and Socratic impulses. Apollonian serenity

63 Silenus: a "companion of Dionysus" $(B T 2)$, whose "wisdom" $(B T 3,4,7,24)$ is "that not to be born is the best of all, and that to be dead is better than to live" (Plutarch, Moralia, vol. 2, trans. Frank Cole Babbit

(Cambridge, MA: Harvard University Press, 1928), 179). Nietzsche evidently relies on a Hellenistic conflation of Silenus (or silens, horse-human hybrids), Pan, and a leader of Dionysus-serving satyrs (Friedrich Nietzsche, The Birth of Tragedy and Other Writings, ed. Raymond Geuss and Ronald Speirs, trans. Ronald Speirs (Cambridge: Cambridge University Press, 1999), 22 n. 37).

64 Compare the contrast between Montaigne's "cheerfulness that really cheers," expressing "certainty and simplicity, courage and strength," and the "cheerfulness" of David Strauss, who "simply does not see the sufferings and the monsters he purports to see and combat" (SE 2). I am grateful to an anonymous referee for noting this connection. For an account of Nietzsche on Montaigne's "cheerfulness" as involving the "overcoming" of a "prior shock or sadness," see also R. Lanier Anderson and Rachel Cristy, "What is 'The Meaning of Our Cheerfulness'? Philosophy as a Way of Life in Nietzsche and Montaigne," European Journal of Philosophy 24.4 (2017): 1514-1549. 
or "coolness" is plausibly the calm of powerful focus or concentration-i.e., an affective state that Nietzsche takes to be elicited by Apollonian-classical forms of simplicity, as described above. This sort of focused calm differs qualitatively from the calm of being untroubled or carefree, à la "Greek cheerfulness" or the "cheerful optimism" of Socratic-theoretical man. But it also differs qualitatively from the calm of disinterestedness in aesthetic experience or in theoretical contemplation. The "coolness" of Socratic dialectic is in turn plausibly related to the latter sort of disinterested states of "will-lessness," not just to the naive optimism that stems from ignoring the Dionysian "abyss."

Before elaborating these last points, it will prove helpful to consider a third reason to be wary of interpreting Greek cheerfulness as anything like a product of one-sidedly Apollonian culture: notwithstanding the above passages, at many other points in $B T$, Nietzsche clearly describes Socratism as being neither Apollonian nor Dionsyian. Kaufmann's account of Socratic culture, as involving a dominant Apollonian drive having formed chaotic Dionysian matter, stands in irreconcilable tension with these Nietzschean descriptions-as does Young's interpretation of Socratism as "the view that reality is Apollonian all the way down."

\section{Socratism as Neither Dionysian nor Apollonian}

A range of textual evidence from $B T$ demonstrates that Nietzsche does not view Socratism as anything like a "too-conclusive victory" of the Apollonian drive (contra Brinton and others). Rather, Nietzsche explicitly characterizes Euripides-whom Nietzsche takes to be responsible for the "death" of classical Greek tragedy — as "merely a mask" out of which a "deity" spoke: "not Dionysus, nor Apollo, but an altogether newborn daemon called Socrates" (B T 12). It would be odd for Nietzsche to describe Socrates as "altogether newborn" vis-à-vis Apollo and Dionysus, if his view were that Socratism is "Apollonianism transformed from a perspective into a metaphysical dogma," as interpreters like Young claim. Rather, in the figure of Socrates, Nietzsche introduces a third basic drive into $B T .^{65}$ Note that this is consistent with the possibility that there could be real and important similarities between the Apollonian and the Socratic, both by contrast to the Dionysian - just as there are real and important similarities between the Apollonian and Dionysian, both by contrast to the Socratic.

After calling Socrates an "altogether newborn daemon," Nietzsche elaborates his view of how Euripides's "Socratic" drama stands in relation to "Apollonian drama" and to "Dionysian" art:

There is not a trace left here [in Euripidean drama] of that epic condition of losing oneself in semblance, of the dispassionate coolness of the true actor who, at the very height of his activity, is nothing but semblance and delight in semblance. Euripides is the actor with the pounding heart, with his hair standing on end; he draws up his plan as a Socratic thinker; he executes it as a passionate actor. Neither in the planning nor in the execution is he a pure artist.[...][I]t is

65 Compare Burnham's claim that "we have to think of three separate drives (the Apollonian, Dionysian, and Socratic" (“Apollo," 77). See also O'Flaherty, "Socrates," 137 n. 5. 
impossible for [Euripidean drama] to achieve the Apollonian effect of epic poetry, but on the other hand it has liberated itself as far as possible from the Dionysian elements, and it now needs new means of stimulation to have any effect at all, means which are no longer part of the only two artistic drives, the Apollonian and the Dionysian. These stimulants are cool, paradoxical thoughtsin place of Apollonian visions - and fiery affects - in place of Dionysian ecstasies - and, what is more, thoughts and affects most realistically imitated, not ones which have been dipped in the ether of art. (BT 12)

Here Nietzsche draws two parallel sets of contrasts, first between "Apollonian visions" and mere "cool, paradoxical thoughts," and then between "Dionysian ecstasies" and mere "fiery affects." He stresses that both mere thoughts and mere affects, in this sense, are totally "new" means of stimulation, which are "no longer part" of the "only" two art-impulses. This suggests that Socratism is not well characterized in terms of an intensified or one-sided view of only Apollonian elements of reality. Rather, Nietzsche seems to be claiming that Socratic "cool, paradoxical thoughts" are different in kind from Apollonian "visions." Even if the intuitive similarities between Socratic and Apollonian modes of "coolly" contemplating clear and distinct forms make it fair to view Socratic "thought" as a degenerate correlate to Apollonian "vision," the crucial point is that this degeneration would not just be a matter of forsaking the Dionysian. Socratism stems from a third basic drive, which perverts Apollonian vision from beyond all art.

Moreover, the parallel contrast that Nietzsche draws between Dionysian "ecstasies" and Euripidean "fiery affects" suggests that Euripides's "aesthetic Socratism" (BT 12) is just as much a degenerate form or expression of the Dionysian as it is a degenerate form of the Apollonian - to the extent that it is either. ${ }^{66}$ On Nietzsche's view, Euripides wrongly took "the effect of tragedy" to stem, not from true "epic suspense," but rather from "those great rhetorical and lyrical scenes in which the passion and dialectic of the protagonist swelled into a broad and mighty stream" ( $B T$ 12). Nietzsche's point is not the intuitive one that Euripides abandoned "Dionysian" passion for "Apollonian" dialectic. Rather, his point is that Euripides abandoned Apollonian vision and Dionysian ecstasy alike, for interrelated Socratic modes of dialectical thought and crass passion. Hence, the Euripidean prologue "illustrate[s][...]his rationalist method" and "aesthetic Socratism" insofar as it totally excludes "anything that was not a preparation for pathos" (BT 12, my emphasis).

Here it might be objected that, when Nietzsche describes "aesthetic Socratism" as "the murderous principle" that destroyed classical Greek tragedy, he apparently claims that "the fight was directed against the Dionysian nature of the older art" (BT 12). But Nietzsche in fact

66 Daniels likewise emphasizes (merely apparent) parallels between Socratism and the Dionysian, not just the Apollonian - see Paul Raimond Daniels, Nietzsche and "The Birth of Tragedy" (London: Routledge, 2014). See also Christopher Janaway, "Beauty is False, Truth Ugly: Nietzsche on Art and Life," in Nietzsche on Art and Life, ed. Daniel Came (Oxford: Oxford University Press, 2014), 39-56, 47; Burnham and Jesinghausen, Reader's Guide, 91. 
says only that "insofar as the fight was directed against the Dionysian nature of the older art, we may identify Socrates as the opponent of Dionysus" (B T 12, my emphasis). This is consistent with "the fight" also having been directed against the Apollonian aspect of tragedy.

Likewise, when he later analyzes "the innermost modern content of [...]Socratic culture" in terms of "the culture of the opera," Nietzsche diagnoses the operatic "stilo rappresentativo" as being "so at odds with the artistic drives of the Apollonian and the Dionysian, that one is bound to conclude that the origin of recitative lies outside all artistic instincts" ( $B T$ 19). Opera is "born of theoretical man, of the layman as critic, not of the artist" (BT 19), on Nietzsche's view:

Because he has no inkling of the Dionysian depths of music, [a man with no artistic capability] transforms for himself the enjoyment of music into the reason-governed rhetoric of passion in sound and word in the stilo rappresentativo, and into the sensuous pleasure afforded by the arts of singing; because he is incapable of seeing a vision, he presses the theatrical technician and stage-decorator into his service; because he cannot grasp the true essence of the artist, he conjures up before his mind's eye 'original man, the artist' in accordance with the demands of his own taste, i.e. a man who sings when he is passionate and who speaks in verse.[...]The precondition of opera is an erroneous belief about the artistic process, or more precisely the idyllic belief that every man of feeling is actually an artist. In line with this belief, opera is the expression in art of the lay mentality which dictates its laws with the cheerful [heitern] optimism of theoretical man. (BT 19)

Operatic culture does not involve abandoning emotion for reason, on Nietzsche's view. Rather, opera involves "the reason-governed rhetoric of passion in sound and word" and "the sensuous pleasure afforded by the art of singing." Nietzsche clearly means these to be explications of the sense in which a total absence of Dionysian "insight" into the "depths of music" manifests in certain aspects of operatic "aesthetic Socratism." But opera also involves features that reflect its unartistic creators being "incapable of seeing a vision," which clearly indicates their lack of strong Apollonian drive. Nietzsche thus diagnoses the modern culture of the opera as being neither Apollonian nor Dionysian, insofar as it is Socratic culture - not as being one-sidedly or "dogmatically" Apollonian.

\section{Apollonian-Classical Calm and "Coldness"}

In order to better understand the contrast between Apollonian and Socratic drives, it will therefore be necessary to more closely examine Nietzsche's notions of "vision" as opposed to "thought," and the "dispassionate coolness of the true actor" as opposed to the dialectician's "cool clarity"-i.e. the "cold" rationality "at any price" ( $T I$ "Socrates" 11) and merciless "knife-thrusts of his syllogisms" that reveal Socrates's irony to be "a form of revenge" or 
"plebeian ressentiment" (TI "Socrates" 7). ${ }^{67}$ Moreover, further illuminating these contrasts will evidently demand more than simply invoking a rationalistic loss of Dionysian insight into nature's "primordial unity" (BT 1), "original pain" (BT 6), uncontrollability, or ineffabilitybecause Socratism is not aptly characterized as an intensified or one-sided expression of the Apollonian drive, or form of attention restricted to (some or all) Apollonian phenomena.

Nietzsche implicitly contrasts the "dispassionate coolness" that he associates with the Apollonian "epic condition of losing oneself in semblance" (BT 12) against the "cool clarity" of Socratic "dialectics" (BT 14). In turn, Apollonian "coolness" is intuitively related to the kind of "calm" or serene "cheerfulness" that Nietzsche also explicitly associates with the Apollonian drive, in $B T$. Hence, for instance, he invokes "the still sea-calm of Apollonian contemplation" ( $B T 6$ ), insists that the poet of dramatized epic "remains a calm, unmoved gaze" (BT 12), and suggests that "[Apollo's] image must include that measured limitation, that freedom from wilder impulses, that wise calm of the image-making god" (BT 1). Likewise, he appeals unironically and respectfully to the "calm" that Apollo brings ( $B T$ 9), to the Olympian gods more broadly as serenely "cheerful [heiteren]" (BT4), and to the air of "superior cheerfulness" in Sophocles's Oedipus cycle (BT 9).

We have already considered a salient contrast class to the serene "cheerfulness" of Apollonian states, for Nietzsche: "Greek cheerfulness," in a pejorative sense. Moreover, I have already suggested what I take to be the most promising way to interpret this contrast. The cheerful calm of Apollonian states is plausibly the calm of powerful focus or concentration. This Apollonian calm is still a state of creative frenzy or intoxication (Rausch), in Nietzsche's later and broader sense of the term. As such, it still involves a real kind of excitation: "sexuality and voluptuousness" are "not lacking in the Apollonian" form of Rausch, which involves an "extreme calm" that is "more strictly" the "retardation of the feelings of time and space" - a "highest feeling of power" that leads one to "react slowly" and experience "no feeling of struggle" (KSA 13:14[46]). ${ }^{68}$ Apollonian calm thus involves freedom from feelings of struggle, due to overpowering strength. That is, it involves freedom from suffering realized, not through self-abnegation or otherworldly indifference to bodily pain, but rather through the ease with which great power overcomes resistance. ${ }^{69}$ By contrast, naive simplicity involves a more reactive exclusion of "the eternal, primal pain" that Dionysian art illuminates (BT 4). The Apollonian is too strong to struggle or to suffer "primal pain," whereas the Socratic naif exists in a state of mere denial about it.

This Apollonian calm of powerful focus plausibly differs qualitatively not only from the calm of being untroubled or carefree, à la Greek cheerfulness construed as a childlike or naive state of "naturalness," but also from the calm of "disinterested" pleasure in aesthetic experience or theoretical contemplation. Hence, for instance, Nietzsche claims that " $[\mathrm{t}] \mathrm{he}$ highest rationality is a cold, clear state very far from giving that feeling of happiness that

67 See also $B T 12$ and 14.

68 WP $§ 799$.

69 See also KSA 12:7[7]. 
frenzy [Rausch] of any kind brings with it" (KSA 13:14[129]). ${ }^{70}$ And his disdain for "disinterestedness" is often still more explicit:

To win back for the man of knowledge the right to great affects! after selfeffacement and the cult of 'objectivity' have created a false order of rank in this sphere, too. Error reached its peak when Schopenhauer taught: the only way to the 'true,' to knowledge, lies precisely in getting free from affects, from will; the intellect liberated from will cannot but see the true, real essence of things.

The same error in arte: as if everything were beautiful as soon as it is viewed without will. $(\text { KSA 12:9[119] })^{71}$

Likewise, Nietzsche challenges the apparently disinterested posture of the Socratic dialectician: "[i]s the irony of Socrates an expression of revolt? Of plebeian ressentiment? Does he, as one oppressed, enjoy his own ferocity in the knife-thrusts of his syllogisms? Does he avenge himself on the noble people whom he fascinates?" (TI "Socrates," 7). ${ }^{72}$

So too, in Essay III, $\S 6$ of GM (1887), Nietzsche criticizes Kant's theory of disinterested pleasure in the beautiful. ${ }^{73}$ Here Nietzsche argues that only someone who theorizes about beauty without "refined first-hand experience" of it would claim that judgments of taste are "impersonal" and "universal," as Kant does (GM III:6). In turn, Nietzsche approvingly cites Stendhal's characterization of the beautiful as une promesse de bonheur (a promise of happiness), elaborating that "to [Stendhal], the fact seems to be precisely that the beautiful arouses the will ('interestedness')" (GM III:6). On Nietzsche's view, Stendhal is evidently a "genuine 'spectator' and artist," who as such understands beauty from a creative standpoint, not that of a creatively inert spectator (GM III:6). Part of what Stendhal sees, as a truly creative artist, is that beauty elicits an "arousal of the will," not the "will-lessness" that Schopenhauer associates with aesthetic experience. And Nietzsche identifies this arousal of will-this creative "frenzy" - with the "interestedness" of artistic responses to beauty.

Here it should be noted that Nietzsche is directly criticizing Schopenhauer, as well as Kant, in $G M$ III.6. Schophenhauer claims that pleasure in beauty arises from selfconsciousness "not as an individual, but as pure, will-less subject of cognition," such that "our attention is no longer directed to the motives of willing but instead grasps things freed from their relation to the will, and hence considers them without interests, without subjectivity, purely objectively." "74 Clearly, then, Apollonian modes of calm or cheerful serenity should not

70 WP $\$ 799(1888)$.

$71 W P \S 612(1887)$.

$72 W P \S 431$. Compare GM III.14: "[t]he will of the weak to represent some form of superiority.” See also GM III: 18.

73 This paragraph and the beginning of the next closely recapitulate part of my analysis in an earlier account of Nietzsche's criticism of Kantian "disinterestedness"- see Eli I. Lichtenstein, "The Passions and Disinterest: From Kantian Free Play to Creative Determination by Power, via Schiller and Nietzsche," Ergo 6.9 (2019): 249-279, 256.

74 Arthur Schopenhauer, The World as Will and Representation, vol. 1, trans. E. F. J. Payne (New York: Dover, 1966), 219. 
be interpreted as Schopenhauerian states of will-lessness-at least not with respect to Nietzsche's mature view.

Notably, however, Nietzsche does draw a positive connection between Apollonian calm and Schopenhauer's metaphysics of will and representation, in BT:

[Apollo's] eye must be 'sun-like'; even when its gaze is angry and shows displeasure, it exhibits the consecrated quality of lovely semblance. Thus, in an eccentric sense, one could apply to Apollo what Schopenhauer says about human beings trapped in the veil of $m \bar{a} y \bar{a}$ : "Just as the boatman sits in his small boat, trusting his frail craft in a stormy sea that is boundless in every direction, rising and falling with the howling, mountainous waves, so in the midst of a world full of suffering and misery the individual man calmly sits, supported by and trusting in the principium individuationis." "I5 Indeed one could say that Apollo is the most sublime expression of imperturbable trust in this principle and of the calm sitting-there of the person trapped within it; one might even describe Apollo as the magnificent divine image of the principium individuationis, whose gestures and gaze speak to us of all the intense pleasure, wisdom and beauty of 'semblance'. (BT 1)

Schopenhauer describes the contemplation of beauty as a "painless state" of temporary "freed[om] from the terrible pressure of the will," in which we "celebrate the Sabbath of the penal servitude of willing." "Willful activity is "penal servitude," for Schopenhauer, because he sees it as an endless cycle of painful alienation from the objects of desire. But the "painless state" of contemplation as a "will-less subject" is not what Nietzsche means by Apollonian "cheerfulness" or "calm," even in his early works. Rather, this Apollonian calm is closer to the "quiet" of man "sitting in the boat," totally caught up in the illusory veil of $m \bar{a} y \bar{a}$-in which state, Schopenhauer says, "his vanishing little person, his unextended present, his momentary comfort, these alone have reality for him."77

The account of Apollonian-classical simplification in section 2, above, helps to clarify what Nietzsche (at least on his mature view) takes this "illusory veil" to comprise, and what it means to apprehend it through "vision" rather than mere "thought." Namely, genuine Apollonian vision is a joyously serene - not a naively cheerful or scientistically disinterestedapprehension of simplified form. This joyous serenity is an artistic state of creative frenzy, or (identically) a feeling of power. But it differs from Dionysian states of frenzy, which are not aptly described as calm or cheerful. Apollonian serenity is the cold but cheerful calm of intense concentration, reflecting both the strong individuality of the powerfully focused subject and the focused clarity of the idealized form or "image" that she contemplates. Apollonian or classical simplification is the process whereby idealized forms of this sort are

75 Schopenhauer, World as Will and Representation, 379.

76 Schopenhauer, World as Will and Representation, 219.

77 Schopenhauer, World as Will and Representation, 379. 
produced. And, on Nietzsche's view, Apollonian-classical simplification or idealization inevitably involves falsification, such that one properly enjoys its products as pure artistic semblance.

Finally, in this light, we may return briefly to scientistic simplicity: the product of a drive to order or simplify experience using "reasonableness" as a criterion for (unartistic) selection. On Nietzsche's view, the "supreme law" of "aesthetic Socratism" is that "[i]n order to be beautiful, everything must be reasonable"" (B T 12). Hence, for example, Euripides introduced the "infamous deus ex machina," as well as a prologue in which a character "who can be trusted" explains "who he is, what precedes the action, what has happened so far, indeed what will happen in the course of the play," so as to "remove all doubts about the reality of the myth" (BT 12). But this "divine truthfulness" was misguided, Nietzsche believes. Euripides and Socrates "did not understand the older tragedy and therefore did not respect it" (BT 12). Indeed:

If [...]it was precisely during their period of dissolution and weakness that the Greeks became ever more optimistic, more superficial, more actorly, but also filled with a greater lust for logic and for making the world logical, which is to say both more 'cheerful' and more 'scientific' - could it then perhaps be the case, despite all 'modern ideas' and the prejudices of democratic taste, that the victory of optimism, the predominance of reasonableness, practical and theoretical utilitarianism, like its contemporary, democracy, that all this is symptomatic of a decline in strength, of approaching old age, of physiological exhaustion? And that pessimism is precisely not a symptom of these things? (BT “Attempt" 4) $)^{78}$

Nietzsche thus takes the Socratic drive to reasonableness that led Euripides to "rectify" every unreasonable element in Greek tragedy (BT 12) to be a symptom of decadence.

But this decadent phase does not reflect "Apollo's harnessing of Dionysus," or a "view of reality as Apollonian all the way down." The "certain deceiving definiteness " or "puzzling depth" of a genuinely Apollonian figure like an Aeschylean tragic hero ( $B T$ 11) does not simply reflect an "arational" Dionysian complement to "rational" Apollonian form. Apollonian form is not essentially rational or reasonable, on Nietzsche's view. It is "clear" $(B T 8,12)$; but Apollonian clarity is not the mass-democratic comprehensibility of Socratic reasonableness.

\section{Apollonian Science}

"Thanks to [Euripides]," Nietzsche objects, "people from everyday life pushed their way out of the audience and on to the stage" ( $B T 11)$. And thanks to the same Socratic impulse to reasonableness that drove Euripides, people from everyday life have also pushed their way onto the stage of scientific thought, such that our basic notions of cognitive order reflect a

78 See also KSA 13:14[92]. 
falling-away from Apollonian or classical ideals. Nietzsche's seemingly ambivalent characterizations of phenomena like logic and science are best viewed in this light.

Sometimes Nietzsche links terms like "logic" and "science" to Apollonian-classical order, as in his claim that "[1] ogical and geometrical simplification is a consequence of enhancement of strength" (KSA 13:14[117]). ${ }^{79}$ Elsewhere, his characterizations of logic and science, or associated phenomena like "calculability," are more neutral or ambiguous. Thus, for instance, "[1] ogic is the attempt to comprehend the actual world by means of a scheme of being posited by ourselves; more correctly, to make it formulatable and calculable for us" (KSA 12:9[97]); or "[s]cience - the transformation of nature into concepts for the purpose of mastering nature-belongs under the rubric "means"” $(K S A \text { 11:26[170] })^{80}$. And in still other cases, his descriptions of phenomena closely related to logic and science are clearly critical. For example:

[A]n interpretation [of the world] that permits counting, calculating, weighing, seeing, and touching, and nothing more - that is a crudity and naiveté, assuming that it is not a mental illness, an idiocy.[...]Assuming that one estimated the value of a piece of music according to how much of it could be counted, calculated, and expressed in formulas: how absurd would such a "scientific" estimation of music be! What would one have comprehended, understood, grasped of it? $(G S 373)^{81}$

Given this wide range, it can be difficult to gauge Nietzsche's stance towards science or logic. Certain of his remarks appear to suggest a Paglia-style ethos of hostility to the (real or perceived) anti-sensualism and excessive universalism of Enlightenment thought. In this spirit, Nietzsche evidently offers a crucial precursor to Heidegger's critique of the modern scientifictechnological reduction of all things to mere "standing-reserve" or "resources" for our own use. Yet in other moments, when he is celebrating Apollonian-classical order as an expression of will to power, Nietzsche appears to hold just the sort of view that critics like Heidegger impute to him.

The present analysis helps to clarify Nietzsche's actual view, and hence his complex historical role in modern critiques of science. While Nietzsche embraces a strikingly aggressive, even systematically appropriative relation to nature, nevertheless he also remains fiercely critical of some of the very same phenomena that critics like Heidegger object to-and associate with Nietzsche. In fact, Nietzsche's criticism of Socratic phenomena like the scientific reduction of nature to mere "formulas" is consistent with his positive descriptions of Apollonian or classical order-including order in the context of cognitive phenomena like logic or science-insofar as he does not take dialectical order to be a true expression or aspect of Apollonian-classical order.

79 WP $\S 800$.

80 WP $§ 610$.

81 Compare KSA 12:7[56]. 
The Socratic "predominance of reasonableness" and "victory of optimism" yield mere thoughts rather than genuine Apollonian visions, and naive "Greek cheerfulness" or scientistic disinterestedness rather than true Apollonian calm. Socratism is not a view of reality as "Apollonian all the way down" (contra Young); it does not reflect "Apollo's harnessing of Dionysus" (contra Kaufmann); it does not stem from a "too-conclusive victory" of the Apollonian drive (contra Brinton); and Socratic rationality is not a "hypertrophied form of one aspect of the Apollonian" (contra Ridley). Nietzsche draws a contrast between two fundamentally distinct kinds of order, and by extension two distinct kinds of clearly structured, broadly scientific thought. I have defended this basic point more fully than others have. And I have offered a distinctive account of what distinguishes the Apollonian-classical and Socratic forms of order.

Apollonian-classical simplification involves a purifying distillation or concentration of things down into purely tonic or strength-enhancing features. This involves artistic idealization, which elicits a feeling of creative frenzy or power-the same feeling that gives rise to art. Apollonian-classical calm is the cold but cheerful calm of intense focus, reflecting the great ease with which the powerfully focused subject overcomes resistance, and the focused clarity of the idealized forms that she enjoys as pure artistic semblance. But Nietzsche associates another kind of order with Socratism as a target of his criticism, and with reasonableness or logic in a pejorative sense. Socratic order comprises naive and scientistic forms of simplicity, which respectively give rise to naively cheerful and scientistically disinterested affective states.

Nietzsche takes Socrates to be altogether newborn: neither Apollonian nor Dionysian. And without fully appreciating this point, one cannot understand his mature view of orderly phenomena like reason, logic, or science-let alone independently assess the possibility or the value of an "Apollonian science." ${ }^{22}$ In this spirit, finally, I will conclude with several brief comments on the nature and value of an idealized Apollonian science. ${ }^{83}$ I make these suggestions primarily in the spirit of possible directions for future research, informed by the above analysis. Deeper engagement with Nietzsche's account of Apollonian-classical order may give rise to a new, more fruitful phase in the analysis of modern scientific culture and its greatest possibilities.

First, it should simply be noted that, insofar as science is by nature orderly (at least on one basic Nietzschean sense of "science"), ${ }^{84}$ Apollonian-classical order may be the best that it can achieve while remaining truly scientific. Second, the link that I have drawn between Apollonian simplicity and idealization suggests that scientific idealization may be an

82 Cf. Oswald Spengler, The Decline of the West: Form and Actuality, trans. Charles Francis Atkinson (New York: Alfred A. Knopf, 1927), 375ff.

83 I.e. a hypothetical form of science best exemplifying Apollonian traits - not a strictly Nietzschean notion, but a reimagining of science that is creatively informed by Nietzsche's notion of Apollonian-classical order. I am grateful to an anonymous referee for requesting a more specific and vivid description of Apollonian science.

84 E.g. 'gay science' may well be less closely related to the Apollonian: medieval troubadours used gaya scienza to refer to the art of poetry; it thus evokes a "unity of singer, knight, and free spirit" (EH "Books: GS"). 
especially fruitful point of connection between science and the Apollonian. ${ }^{85}$ More broadly, certain actual scientific practices are likely more relevant to the idea of an Apollonian science than are others - which, in turn, could motivate an evaluative reorientation of science towards these specific practices, like idealization. ${ }^{86}$ Third, Nietzsche's account of Apollonian or classical calm suggests that an Apollonian science would manifest in a distinctive kind of coldness, hardness, or anti-sentimentality, which is neither "disinterested" nor "reasonable," as in traditionalistic ideals of scientific inquiry; but which also involves freedom from both melodramatic Euripidean "affects" and genuine Dionysian "ecstasies." Pursuing this aspect of Nietzsche's account may therefore illuminate the phenomenological dimension of a distinctive and potentially higher form of scientific objectivity. Fourth and most speculatively, the later Nietzsche arguably entertains the idea that phenomena like logic and thinking are, in their Apollonian forms, best understood by analogy to inorganic will to power-like "the imposition of forms [...] in the case of crystal." $"$ Focus on Apollonian order may thus clarify not only the epistemological or aesthetic dimensions of science, but also its basic ontological character. The highest kind of scientific thought may be just one among many forms of "crystalline" or quasi-inorganic will to power within nature.

85 One cannot simply assert that scientific idealization (as in modeling an "ideal gas") is Apollonian idealization, of course. What is at stake, rather, is whether it might be possible to perform scientific idealizations via broadly artistic simplification down to "tonic" features, e.g. as opposed to "reasonable" features. I do not claim that Nietzsche himself explicitly links Apollonian and scientific idealization.

86 One might link Apollonian idealization to broader anti-realism, constructivism, or fictionalism about objects, which some have attributed to Nietzsche (see e.g. Rex Welshon, "Saying Yes to Reality: Skepticism, Antirealism, and Perspectivism in Nietzsche's Epistemology," Journal of Nietzsche Studies 37 (2009): 23-43; Justin Remhof, Nietzsche's Constructivism: A Metaphysics of Material Objects (New York: Routledge, 2017); see also n. 48 and references therein). My account here is compatible with various views on this broader issue. But it may be helpful to focus on issues like scientific idealization, to achieve finer-grained analysis of scientific practices and their value.

87 Compare n. 43, n. 44, and n. 45, above, as well as the corresponding main text. 


\section{REFERENCES}

$\begin{array}{ll}\text { Abbreviations: } \\ \text { A } & \text { The Antichrist } \\ B G E & \text { Beyond Good and Evil } \\ B T & \text { The Birth of Tragedy } \\ \text { EH } & \text { Ecce Homo } \\ G M & \text { On the Genealogy of Morality } \\ G S & \text { The Gay Science } \\ \text { KSA } & \text { Kritische Studienausgabe } \\ T I & \text { Twilight of the Idols } \\ W P & \text { The Will to Power } \\ Z & \text { Thus Spoke Zarathustra }\end{array}$

\section{Works Cited:}

Anderson, R. Lanier (2005). "Nietzsche on Truth, Illusion, and Redemption." European Journal of Philosophy 13(2):185-225.

Anderson, R. Lanier and Rachel Cristy (2017). "What is 'The Meaning of Our Cheerfulness'? Philosophy as a Way of Life in Nietzsche and Montaigne." European Journal of Philosophy 24(4): 1514-1549.

Bauemer, Max L. (1976). "Nietzsche and the Tradition of the Dionysian." In James C. O'Flaherty, Timothy F. Sellner, and Robert M. Helm (Eds.), Studies in Nietzsche and the Classical Tradition (Chapel Hill: University of North Carolina Press), 165-189.

Bishop, Paul, and R.H. Stephenson (2005). Friedrich Nietzsche and Weimar Classicism. Camden House.

Brinton, Crane (1948). Nietzsche. Harvard University Press.

Brobjer, Thomas H. (2005). Sources of and Influences on Nietzsche's The Birth of Tragedy. Nietzsche Studien 34(1): 278-299.

Burnham, Douglas and Martin Jesinghausen (2010). Nietzsche's The Birth of Tragedy: A Reader's Guide. London: Continuum.

Burnham, Douglas (2014). Apollo and the Problem of the Unity of Culture in the Early Nietzsche. In Anthony K. Jensen and Helmut Heit (Eds.), Nietzsche as a Scholar of Antiquity (London: Bloomsbury), 75-95.

Clark, Maudemarie (1987). Deconstructing the Birth of Tragedy. International Studies in Philosophy 19(2):67-75.

Clark, Maudemarie (1990). Nietzsche on Truth and Philosophy. Cambridge University Press. 
Daniels, Paul Raimond (2014). Nietzsche and The Birth of Tragedy. London: Routledge.

Doyle, Tsarina (2018). Nietzsche's Metaphysics of the Will to Power: The Possibility of Value. Cambridge.

Emden, Christian J. (2004). The Invention of Antiquity: Nietzsche on Classicism, Classicality, and the Classical Tradition. In Paul Bishop (Ed.), Nietzsche and Antiquity: His Reaction and Response to the Classical Tradition (Rochester: Camden House), 372-390.

Galison, P. and Stump, D. (eds.). (1996). The Disunity of Science. Boundaries, Contexts and Power. Stanford University Press.

Heidegger, Martin (1977). The Question Concerning Technology and Other Essays. Trans. William Lovitt. New York: Garland.

Heidegger, Martin (1991). Nietzsche. Translated by David Ferrell Krell. San Francisco: Harper Collins.

Held, Dirk t.D. (2004). Conflict and Repose: Dialectics of the Greek Ideal in Nietzsche and Winckelmann. In Paul Bishop (Ed.), Nietzsche and Antiquity, 411-424.

Hempel, Carl G. (1965). Aspects of Scientific Explanation. New York: The Free Press.

Hempel, C. G., (2000). Selected philosophical essays. Ed. Richard Jeffrey. Cambridge University Press.

Huddleston, Andrew (2019). Nietzsche on the Decadence and Flourishing of Culture. Oxford.

Hussain, Nadeem (2004). "Reading Nietzsche Through Ernst Mach.” In Gregory Moore and Thomas H. Brobjer (eds.), Nietzsche and Science (London: Routledge), 111-129.

Janaway, Christopher (2014). "Beauty is False, Truth Ugly: Nietzsche on Art and Life.” In Daniel Came (ed.), Nietzsche on Art and Life (Oxford: Oxford University Press), 39-56.

Jung, C. G. (2017). "The Apollinian and the Dionysian.” In R. F. C. Hull and H. G. Baynes (Trans.), Psychological Types (London: Routledge), 125-135.

Jünger, Ernst (1993). “Total Mobilization.” In Richard Wolin (Ed.), The Heidegger Controversy: A Critical Reader (Cambridge, MA: The MIT Press), 119-139.

Kalar, Brent (2008). The Naive and the Natural: Schiller's Influence on Nietzsche's Early Aesthetics. History of Philosophy Quarterly, 25(4), 359-377.

Kant, Immanuel (1998). Critique of Pure Reason. Translated by Paul Guyer and Allen W. Wood. Cambridge.

Kaufmann, Walter (1974). Nietzsche: Philosopher, Psychologist, Antichrist. Princeton.

Leiter, Brian (2015). Nietzsche on Morality, $2^{\text {nd }}$ Ed. London: Routledge.

Lichtenstein, Eli I. (2019). "The Passions and Disinterest: From Kantian Free Play to Creative Determination by Power, via Schiller and Nietzsche." Ergo, An Open Access Journal of Philosophy 6: 249-279.

Loeb, Paul S. (2015). "Will to Power and Panpsychism: A New Exegesis of Beyond Good and Evil 36.” In Manuel Dries and Peter J. Kail (Eds.), Nietzsche on Mind and Nature (Oxford 
University Press), 57-88.

Magnus, Bernd (1988). "The Use and Abuse of The Will to Power." In R. Solomon and K. Higgins (eds.), Reading Nietzsche (Oxford: Oxford University Press), 218-235.

Merwin, Christopher, Aaron James Wendland, and Christos Hadjioannou (2019). "Introduction: Heidegger's Thinking Through Technology.” In Merwin, Wendland, and Hadjioannou (Eds.), Heidegger on Technology (London: Routledge), 1-12.

Mulhall, Stephen (2014). "Orchestral Metaphysics: The Birth of Tragedy between Drama, Opera, and Philosophy." In Daniel Came (ed.), Nietzsche on Art and Life (Oxford: Oxford University Press), 107-126.

Nehamas, Alexander (2017). "Nietzsche on Truth and the Value of Falsehood." Journal of Nietzsche Studies 48(3):319-346.

Nietzsche, Friedrich (1966). Beyond Good and Evil (Walter Kaufmann, Trans.). Vintage.

Nietzsche, Friedrich (1967). The Birth of Tragedy and the Case of Wagner (Walter Kaufmann, Trans.). Vintage.

Nietzsche, Friedrich (1968). The Will to Power (Walter Kaufmann and R. J. Hollingdale, Trans.). Vintage.

Nietzsche, Friedrich (1974). The Gay Science: With a Prelude in Rhymes and an Appendix in Songs (Walter Kaufmann, Trans.). Vintage.

Nietzsche, Friedrich (1976). Thus Spoke Zarathustra (Walter Kaufmann, Trans.). In Walter Kaufmann (Ed.), The Portable Nietzsche (103-439). Penguin.

Nietzsche, Friedrich (1976). Twilight of the Idols (Walter Kaufmann, Trans.). In Walter Kaufmann (Ed.), The Portable Nietzsche (463-564). Penguin.

Nietzsche, Friedrich (1989). On the Genealogy of Morals and Ecce Homo (Walter Kaufmann and R. J. Hollingdale, Trans.). Vintage.

Nietzsche, Friedrich (1999). The Birth of Tragedy and Other Writings. Edited by Raymond Geuss and Ronald Speirs. Translated by Ronald Speirs. Cambridge University Press.

Nietzsche, Friedrich (1999). Friedrich Nietzsche: Sämtliche Werke: Kritische Studien Ausgabe (15 Vols., G. Colli and M. Montinari, Eds.). Walter de Gruyter.

O’Flaherty, James C. (1976). "Socrates in Hamann's Socratic Memorabilia and Nietzsche's Birth of Tragedy.” In James C. O'Flaherty et al. (Eds.), Studies in Nietzsche and the Classical Tradition, 134-143.

Paglia, Camille (1991). Sexual Personae: Art and Decadence from Nefertiti to Emily Dickinson. New York: Vintage Books.

Plutarch (1928). Moralia, Vol. 2. Translated by Frank Cole Babbit. Harvard University Press.

Porter, James I. (2000). The Invention of Dionysus: An Essay on The Birth of Tragedy. Stanford University Press.

Remhof, Justin (2017). Nietzsche's Constructivism: A Metaphysics of Material Objects. Routledge. 
Rethy, Robert (1991). “Schein in Nietzsche’s Philosophy.” In Keith Ansell-Pearson (Ed.),

Nietzsche and Modern German Thought (London: Routledge), 59-87.

Richardson, John (1996). Nietzsche’s System. Oxford.

Ridley, Aaron (2007). Nietzsche on Art. London: Routledge.

Schopenhauer, Arthur (1966). The World as Will and Representation (Vol. 1). Translated by E. J. F. Payne. Dover.

Siemens, Herman (2004). Nietzsche and the 'Classical': Traditional and Innovative Features of Nietzsche's Usage, with Special Reference to Goethe. In Paul Bishop (Ed.), Nietzsche and Antiquity, 391-410.

Spengler, Oswald (1927). The Decline of the West: Form and Actuality. Translated by Charles Francis Atkinson. New York: Alfred A. Knopf.

Stoll, Timothy (2019). "Nietzsche and Schiller on Aesthetic Semblance." The Monist 102: 331348.

Thomson, Iain (2011). Heidegger, Art, and Postmodernity. Cambridge.

Thomson, Iain (2019). “Technology, Ontotheology, Education.” In Aaron James Wendland, Christopher Merwin, and Christos Hadjioannou (Eds.), Heidegger on Technology (London: Routledge), 174-193.

Welshon, Rex (2009). "Saying Yes to Reality: Skepticism, Antirealism, and Perspectivism in Nietzsche's Epistemology.” Journal of Nietzsche Studies 37: 23-43.

White, Richard (1988). Art and Individual in Nietzsche's Birth of Tragedy. British Journal of Aesthetics 28(1): 59-67.

Williams, Bernard (2001). "Introduction." In Friedrich Nietzsche, The Gay Science: With a Prelude in German Rhymes and an Appendix in Songs (Cambridge: Cambridge University Press), vii-xxii.

Williams, Linda L. (1996). "Will to Power in Nietzsche's Published Works and the Nachlass." Journal of the History of Ideas 57(3): 447-463.

Winckelmann, Abbé (1765). Reflections on the Painting and the Sculpture of the Greeks. Trans. Henry Fuselli. London: A. Millar.

Yates, Peter (2004). Nietzsche, Aristotle, and Propositional Discourse. In Paul Bishop (Ed.), Nietzsche and Antiquity, 70-78.

Young, Julian (2002). Heidegger's Later Philosophy. Cambridge.

Young, Julian (2006). Nietzsche's Philosophy of Religion. Cambridge.

Young, Julian (2013). The Philosophy of Tragedy: From Plato to Žižek. Cambridge.

Zimmerman, Michael E. (1990). Heidegger's Confrontation with Modernity: Technology, Politics, and Art. Indiana University Press. 